\title{
Understanding the Forms and Trends of Capital Mobility from China into Ghana's Agricultural Sector: From Neo-liberalism to Social Innovation
}

\author{
John Windie Ansah ${ }^{1} \&$ Benedict Afful ${ }^{2}$
}

\section{Abstract}

Given the fact that China has become the top investor in Ghana's economy, this paper sought to interrogate the forms and trends of Chinese capital mobility into Ghana's agricultural sector and explain their attractiveness within neo-liberal and social innovation contexts. Primary and secondary data were drawn from purposively selected state institutions and other actors in the agricultural sector. Using descriptive and constant comparative analytic strategies, we found out that the capital mobility from China into Ghana's agricultural sector has been very visible and more attractive in trade but not in landed investment. It was further discovered that, the forms and trends of the Chinese capital mobility would not have to be understood within neo-liberal persuasions such as trade liberalization and privatization alone
\end{abstract}

but it would also have to be understood within the social innovative contexts of technological advancement and the organizational novelties upon which it is promoted and spread. We argue that the increasing rate of importation of agricultural inputs from China is an opportunity for knowledge transfer and technological adoption to aid the development of appropriate technology, but its sustenance would require the application of social innovative practices.

Keywords: Capital mobility, neoliberalism, political economy heteredoxy, social innovation, china, ghana 


\section{Introduction}

Serving as a source of foreign exchange, employment, reducing expenditure on importation, enhancing food security and acting as a source of foreign exchange, agriculture remains the real foundation of every country's economic development (Todaro \& Smith, 2009). In Africa, for example, agriculture accounts for 33 percent of its GDP (New African, 2014). Its capacity to reduce poverty cannot be equally overemphasized because investment in agriculture, according to Moyo (2014), could lift 85 million people out of poverty by 2024 . In Ghana, for example, agriculture's vitality to enhance crop production and employment remains apparent as it absorbs about 45 per cent of the work force (Okudzeto, Mariki, De Paepe \& Sedegah, 2014). These realities signify the enormous potential in Africa's agricultural sector.

$$
\text { Africa's agricultural }
$$

potential has attracted tremendous capital mobility (Alden, 2013; Brautigam, 2015; Buckley, 2013) which finds expression in Foreign
Direct Investment (FDI), trade, and inventor mobility. Even though the reasons for the attraction may not be far-fetched, Hallam (2009) puts it in a more elaborate and succinct fashion. $\mathrm{He}$ notes:

"A major underlying driver for the recent spate of interest [trade] in international investment in food production appears to be food security and a fear arising from the recent high food prices and policy-induced supply shocks that dependence on world markets for foods supplies or agricultural raw materials has become riskier" (p.2) [emphasis added].

On account of the developmental outcomes of the FDI and trade in the agricultural sector they have generated controversial economic, political, institutional, legal and ethical issues with complex debates about whether or not these investments should be encouraged. While some regard it as an expression of South-South cooperation others regard it as a neo-imperialist expansionism. But whatever, the case may be agriculture is of 
strategic value to the political economy of China (Mueller \& Mueller, 2014).

Putting Ghana on the spotlight, she has also attracted some enormous investments from development partners and foreign investors given the fact that productivity increases in Ghanaian agriculture are potentially significant (World Trade Organization, 2014). The benefits of these investments cannot be overlooked considering Ghana's infrastructural deficits which currently require sustained spending of at least US\$ 1.5 billion per annum over the next decade (Ministry of Finance and Economic Planning, 2013) and the fact that Ghana lacks the financial wherewithal to quickly address these deficits. One of these partners is China.

Chinese position as a top investor weaves into her 'going out' policy which encourages Chinese firms including agricultural parastatals to invest in a host of countries with myriad of incentives offered through the China Africa Development Fund (Xu et al., 2016). Consequently, China has strengthened itself as a leading player in the world economy, challenging the dominance of the United States (Scoones, Amanor, Favareto, \& Qi, 2016).

In addition, China also presents itself as more assertive in her intent of being at the core of the "multilateral debate about the reconfiguration of global governance mechanisms" (Vaz, 2015: 1). In Africa, its influence on the scope and amount of both development assistance and investment in agriculture in Africa is growing significantly (Buckley, 2013). In Ghana, China's influence has also been felt. In 2011 Ghana experienced 79 Chinese investment projects registered with the total value of \$145 million, while in 2012 China registered 56 projects making it a top investor in Ghana in terms of number of registered projects (GIPC, 2013) cutting across all sectors of the economy.

As China makes this long march into Ghana's economy, many questions stir the intuitions of many political economists and development analysts particularly about what China seems to bring to Ghana's agricultural sector. 
These questions have not been fully answered because the trudge to search the real facts about China's role in Ghana's agriculture has either not been well ignited or perhaps got stalled. A generally question we seek to ask is, does neo-liberalism provide all the explanations? In other words, can heterodox political economy, which finds expression in social innovation, also provide useful explanations? In this paper, the scope of capital mobility will be limited to foreign direct investment and trade alone. Inventor mobility was not considered because there was lack of data that would have helped in the analysis of the patterns and the context within which they it occurs.

As it stands now, intellectual discourse of Ghana's agricultural regime has concentrated on the internal contradictions in the sector and the role of internal actors in the improvement of the sector (Moyo, 2014, Seini, 2003; Asamoa, 2001; Nyanteng \& Dapaah, 1993). Besides this, even though studies on China-Ghana relations exist, these studies have generally concentrated on trade, manufacturing, road infrastructure development, energy (Tsikata, Fenny \& Aryeetey 2008, Marfaing \& Theil 2011; Glaesel \& McCraken, 2012; Tang, 2017).

Existing studies give a rather superficial outlay on how Chinese foreign aid works to promote Ghana's agricultural sector (Idun-Arkhurst, 2008; Amanor, 2013). Subsequently, other studies which provide rich intellectual analyses on the Chinese role in Ghana's agricultural sector have been carried out (see Amanor \& Chichava, 2016; Scoones et al., 2016). However, the studies were not focused exclusively on China and Ghana hence the information about China's role in Ghana's agricultural sector in these studies seem to have been subsumed by information about other countries. Consequently, it blurs the detailed picture one needs to obtain to enhance useful discussions and inform agriculture-related policy strategies.

Clearly, the spectra within which the afore-mentioned studies have been carried suggest that attention could still be given 
to the agricultural sector but, this time round, on how China may have been contributing to the sector's prospects or otherwise in a detailed manner.

As established in the literature, fast-growing locations are not closed and independent economies, but rather they are, most likely, those areas hosting Multinational Enterprises (MNEs) (Walker, 1978; Isaksson, 2001; McCann \& Acs, 2009). Over, the years the discussion of China's long march in Africa's agriculture has been situated within the contexts of neo-liberalism with some specific explanations.

Much as we also wish to situate this work into neoliberalism, we seek to do this with the intention of contesting some of the existing neo-liberal arguments and then introduce other contexts which depart from political economy orthodoxy. The new drift to this orthodoxy is known as heterodox political economy. Invariably, we seek to interrogate the social innovative strengths of Chinese firms in their quest to remain more assertive in their intent of being at the core of the reconfiguration of global economic mechanisms including Africa and Ghana.

On grounds of these contestations and research gaps, we locate the role of China, as an external actor; in Ghana's agricultural sector on the altar of three concepts namely capital mobility, neo-liberalism and social innovation couched within political economy frameworks. We choose to locate this study within political economy frameworks because, as Scoones et al. (2016) point out, intellectual discourse about Chinese engagements in African agriculture must look beyond the descriptive narratives and "look at the dynamic and uncontested politics of engagement as new forms of capital and technology enter the African context" (p.1). With these in focus, this study sought to address:

1. How the patterns of capital mobility have occurred in the various sub-sectors

2. The unspoken neo-liberal contexts within which the patterns of capital mobility have taken place 
3. The social innovation contexts within which the patterns have occurred

\section{Literature Review}

Capital Mobility in the Context of Political Economy Heterodoxy

Capital mobility is commonly described as the process through which the flow of capital carried out through trade, foreign direct investment and inventor mobility (see Coe \& Helpman, 1995; Aitken \& Harrison, 1999; Almeida \& Kogut, 1999; Keller, 2002; Javorcik, 2004; Bitzer \& Geischecker, 2006; Oettl \& Agrawal, 2008; Kang, 2015) from members of one social system to another social system who do not share the same national territorial boundary.

Largely then, capital mobility is accountable for the nature of items being spread on the altar of globalization. Specifying the items being spread, Snyder (1999) argues that the social processes of globalization involve the spread of particular means of production and patterns of consumption. As a matter of fact, international capital mobility has increased notably in the past decades: on the one hand, the dispersion of international investments across different countries has increased; on the other hand, it tends to concentrate in a few regions within these. Locations where MNEs invest thus become part of global production networks (GPN) at different stages of the production process (Ernst \& Kim, 2002).

Heterodox political economy makes a case for the role of other institutions and other social arrangements which are neither essentially economic nor political. Hence, the heterodox political economy perspective holds the role of globalization expressed in capital mobility, as a tool for reengineering regional economic processes, is conditioned to economic, political and social conditions. This perspective suggests that capital mobility may rely not only on the availability of natural resources and neo-liberal or statist macroeconomic structures. Rather, improved economic infrastructure such as development of transportation and 
communication systems may influence the pace of capital mobility and eventually affect regional economic development process (Marx, 1967).

Extending this scope, heterodox political economy further notes that enhancement of capital mobility is equally hinged on the non-physical aspects. As argued in the literature, capital mobility into hosting MNEs is influenced by financial capabilities ranging from their sales efforts to reduced turnover time on fixed capital (Harvey, 1975) as well as technical innovation, organizational change (Walker, 1978), financial liberalization policies (Isaksson, 2001) and international investment (McCann \& Acs, 2009).

Furtherance to the arguments above, Piore and Sabel (1984) contend that flexible specialisation, trust and face-toface social relations are fundamental requirements for regional economic success in an era of global economic expansion. Adding the political dimension to the capital mobility-regional development mix, Coe, Hess,
Yeung, Dicken and Henderson (2004) suggest that regional development happens on an uneven power playing field.

More specifically, they claim that the balance of power between the different actors is an important determinant of the potential for value enhancement and value capture. It is therefore clear that the mobility of capital and its improvement thereof are hinged on a deep interrelationship between both the physical and the non-physical factors cutting across economic, political and social spectra. Heterodox political economy also finds expression in social innovation.

Social Innovation: A Dimension of Political Economy Heterodoxy

Social innovation is generally defined as effort, method, result or change by collaborative actions (Howaldt \& Schwarz, 2010; Neumeir, 2012). Characteristically, social innovation may take varied approaches namely technological, entrepreneurial, organizational and sociological. In this paper, we focus on organizational innovation because its content 
resonates with the focal point of this paper which interrogates the organizational strength of Chinese firms in their quest to remain more assertive in their intent of being at the core of filling some economic gaps in Ghana's agricultural sector.

Organizational

innovation is that form of innovation described as a new form of cooperative entrepreneurial acting principally resulting into new forms of organization and resulting in technical and marketing innovations (Schumpeter, 1934, 2004). Pot and Vass (2008) view it as containing features such as dynamic management, flexible organization, working smarter, development of skills and competencies and networking with organizations which are seen as been complimentary to technological innovation. Social innovation emerges as one of the social contexts which occasion the process of capital mobility thus operates as one of the strands of political economy heterodoxy. Given the nature of social innovation it reflects the essence of political economy heterodoxies because it would explain the dynamics with which Chinese capital mobility assumes preponderance in Ghana's agricultural sector by referring to non-political and non-structural economic conditions.

Judging from the arguments on social innovation, it can be summed up that a successful social innovation endeavour would require: Creativity, competency, commitment, collaboration and co-operation. Even though the focus is actually on the organisational innovation level at which the issues of social innovation are associated with the Chinese presence in Ghana's agricultural sector, much of the attention will also be given and located at the marketing level (after-production innovation).

In this paper, organisational innovation can be used in coterminous terms with the term social innovation because the difference between purely organizational innovations and social innovations, as Neumeir (2012) said, is "not always precisely considered" (p.50). On grounds of this clarification and the description of the nature, 
content, futures and requirements of social innovation, this strand of political economy heterodoxy will serve as useful context for analysing some of the political economy heterodoxies associated with Chinese presence in Ghana's agricultural sector.

\section{Methodology}

The study was essentially descriptive and exploratory. Philosophically, the study is largely rooted in the pragmatic paradigm to knowledge production. Situating the orientations of the philosophical paradigm into this research we sought to describe the trends and forms with which the Chinese capital mobility has taken roots in Ghana's agricultural sector. In addition, we engaged the respondents to capture their encounters and motivations associated with the patronage of Chinese agricultural input. On grounds of the consistency between the orientations of the pragmatic paradigm to research and the nature of the research qualitative and quantitative methods were employed in a sequential order with the latter method preceding the former.

Both quantitative and qualitative data were used. The quantitative data were drawn from secondary sources. The secondary data were sourced from Ghana Investment Promotion Authority, Fisheries Commission and Ministry of Trade and Industry. The qualitative data were however, sourced from public institutions, private institutions (producers and distributors) and end-users. Specifically, Table 1 shows the source and the number of respondents obtained from each source of the primary data. 
Table 1: Primary Sources

\begin{tabular}{|c|c|c|}
\hline Category & Source & Sample \\
\hline \multirow[t]{3}{*}{ Public Institutions } & Agricultural $\quad$ Engineering & 6 \\
\hline & Services Directorate (AESD) & \\
\hline & $\begin{array}{l}\text { Ministry of Food and } \\
\text { Agriculture }\end{array}$ & 2 \\
\hline \multirow{5}{*}{$\begin{array}{l}\text { Private Institutions (Producers } \\
\text { and Distributors) }\end{array}$} & WYNCA & 2 \\
\hline & JOYVET & 3 \\
\hline & Agro-chemical Retailers & 5 \\
\hline & RST & 4 \\
\hline & Motorking & 1 \\
\hline \multirow[t]{3}{*}{ End-users } & Meat Producers & 7 \\
\hline & Aqua culturist & 7 \\
\hline & Farmers' Association & 8 \\
\hline Total & & 45 \\
\hline
\end{tabular}

Source: Authors' own construction, 2018

We deployed purposive as the technique to select the target respondents because they were well-positioned to articulate the context of the increasing levels of patronage and imports of Chinese agricultural inputs and provide secondary information on Chinese capital mobility into Ghana's agricultural sector is concerned (Palys, 2012). Officials from the Ministry of Food and Agriculture, AESD and the Fisheries Commission were selected using 'expert' purposive sampling technique to select them because they "have a particular expertise that is most likely to be able to advance our interest as researchers and potentially open new doors" (Given, 2008:2) with regard to the patterns and attractions of Chinese capital mobility and the neoliberal and social innovation contexts within which Chinese capital will be understood. We further used the 'criterion' purposive sampling to select the retailers, the meat producers, the aqua culturists as well as leaders and members of various farmers' associations because they had 
some life experiences and motivations for patronage with regard to the mobility of capital and diffusion of knowledge from China (Given, 2008:2) which provided considerable contextual understanding of how social innovation was inclined to the patronage of Chinese agricultural input.

In-depth interviews were conducted involving the use of interview guides. A total of $13 \mathrm{key}$ informants were interviewed. Focus Group Discussions (FGD) were also deployed involving the use of FGD guides. The FDGs were limited to the engineers of the AESD and the end-users given their uniformity of exposure and the variations in their encounters with Chinese agricultural inputs. In all, 5 FDGs were formed for the discussions. The groups were constituted, in their respective terms, by 4 engineers, 5 agrochemical retailers, 6 meat producers, 6 aqua culturists, and 8 members of the farmers' association. The discussion process was fashioned out to reveal underlying views and motivations, behavioural triggers and challenges and explored reactions to messages (Wallace \& Sheldon, 2015) about capital mobility from China.

The process of gathering data from the respondents involved the 'Sense Maker' approach. This approach gave a deeper sense of the underpinning motivations of Ghanaians interest in Chinese agricultural inputs. By this approach, we used the following strategies:

1. Sought experiences from respondents as they conveyed complex knowledge through their stories rather than merely seeking their opinions.

2. Used indirect promptings to elicit answers that tended to be more honest and revealing.

Practically, in combining these strategies, the research participants were made to compare their experiences with the agricultural input from China and from other countries in order to establish the veracity of the emerging heterodoxies in Chinese capital mobility. 
The analysis of primary data involved a "range of techniques for sorting, organising and indexing" (Mason, 1996:7). The primary data were organized into themes (data set) which contained similar responses and meaning from the multiple research respondents (Ayres, Kavanaugh \& Knafl, 2003). Themes were then developed as fashioned out along the specific issues which emerged from the participants' responses during the period of data collection.

Afterwards the contents of the themes were used to explore the relevance of the heterodox political economy theory to the responses derived from the respondents. Certain social processes, social innovation contexts became central to the understanding of how the actors in the agricultural patronised Chinese agricultural inputs using insights from literature. For this reason, the study employed the constant comparative analytic strategy through which the fundamental social processes which characterize the patronage of imported items and their usage by actors in agricultural sector were analysed by drawing out similarities and differences in encounters and motivations (Thorne, 2000). The secondary data were presented in figures and tables to establish the trends and the forms of the capital mobility.

\section{Results and Discussion}

This section presents the forms and trends of capital mobility from China into Ghana's food production sector. It starts by ascertaining the forms and trends of capital mobility from China into Ghana's agricultural sector. It presents the patterns of Foreign Direct Investment (FDI), in terms of number of investments and capital invested into Ghana's agricultural sector and their geographical distributions as well as the year-on-year add ups in terms of trade of Chinese agricultural input. Subsequently, it presents the neo-liberal and the social innovation contexts associated with the forms and trends of the capital mobility.

Forms and trends of Capital Mobility from China into Ghana's Agricultural Sector - FDI 
John Windie: Understanding the Forms and Trends of Capital Mobility from China into Ghana's Agricultural Sector:

The rationale for highlighting the forms and trends of Chinese investment-related capital mobility into Ghana's agricultural sector is to establish the extent and the industries within the agricultural sector within which the Chinese are contributing to the sector.

Capital Mobility in Ghana's Crop and Animal Husbandry Subsectors

Table 2 provides details of Chinese investments in the crop and animal husbandry subsectors.

Table 2: Composite Profile of Chinese Companies engaged in Ghana's Agricultural Sector

\begin{tabular}{|c|c|c|c|c|c|c|c|}
\hline $\begin{array}{l}\text { Company } \\
\text { Name }\end{array}$ & Date_Iss & Location & Region & Country & Ownership & Sector & Activity \\
\hline $\begin{array}{l}\text { Golden Fish } \\
\text { Aquaculture } \\
\text { Ltd }\end{array}$ & 06/02/1997 & Tema & $\mathrm{Gr}$ & China & $\mathrm{F}$ & Agric & $\begin{array}{l}\text { Fish } \\
\text { Farming } \\
\text { and } \\
\text { Aquarists }\end{array}$ \\
\hline $\begin{array}{l}\text { Meilong } \\
\text { Poultry Ltd }\end{array}$ & $22 / 04 / 1997$ & Tema & Gr & China & $\mathrm{F}$ & Agric & $\begin{array}{l}\text { Poultry } \\
\text { Complex }\end{array}$ \\
\hline $\begin{array}{l}\text { Eau } \\
\text { Agricultural } \\
\text { Company } \\
\text { (Gh) Ltd }\end{array}$ & 29/09/1999 & $\begin{array}{l}\text { Amasam } \\
\text { an }\end{array}$ & $\mathrm{Gr}$ & China & $\mathrm{Jv}$ & Agric & $\begin{array}{l}\text { Poultry } \\
\text { Farming }\end{array}$ \\
\hline $\begin{array}{l}\text { Santa } \\
\text { Fisheries } \\
\text { (Gh) Ltd }\end{array}$ & $19 / 05 / 1999$ & Tema & $\mathrm{Gr}$ & $\begin{array}{l}\text { China/T } \\
\text { aiwan }\end{array}$ & $\mathrm{Jv}$ & Agric & Fishing \\
\hline $\begin{array}{l}\text { Henz Poultry } \\
\text { Ltd Now } \\
\text { Dragon } \\
\text { Farming Ltd }\end{array}$ & $12 / 09 / 2001$ & Tema & $\mathrm{Gr}$ & China & $\mathrm{F}$ & Agric & $\begin{array}{l}\text { Poultry } \\
\text { Productio } \\
\mathrm{n}, \\
\text { Hatchery, } \\
\text { Feed } \\
\text { Manufact } \\
\text { uring }\end{array}$ \\
\hline $\begin{array}{l}\text { Big Catch } \\
\text { Fisheries } \\
\text { (Gh) Ltd }\end{array}$ & $17 / 10 / 2002$ & Tema & $\mathrm{Gr}$ & China & $\mathrm{Jv}$ & Agric & $\begin{array}{l}\text { Tuna } \\
\text { Fishing }\end{array}$ \\
\hline $\begin{array}{l}\text { Hauang Jia } \\
\text { Yi Limited }\end{array}$ & $15 / 06 / 2007$ & Tema & $\mathrm{Gr}$ & China & $\mathrm{Jv}$ & Agric & $\begin{array}{l}\text { Vegetable } \\
\text { Farming: } \\
\text { Chinese } \\
\text { Cabbage, }\end{array}$ \\
\hline
\end{tabular}


John Windie: Understanding the Forms and Trends of Capital Mobility from China into Ghana's Agricultural Sector:

\begin{tabular}{|c|c|c|c|c|c|c|c|}
\hline & & & & & & & $\begin{array}{l}\text { Lettuce, } \\
\text { Green } \\
\text { Pepper } \\
\text { Etc. }\end{array}$ \\
\hline $\begin{array}{l}\text { Heyi } \\
\text { Company } \\
\text { Limited }\end{array}$ & $28 / 06 / 2007$ & $\begin{array}{l}\text { Kpong\& } \\
\text { Ahweras }\end{array}$ & $\mathrm{Vr}$ & China & $\mathrm{Jv}$ & Agric & $\begin{array}{l}\text { Vegetable } \\
\text { Farming }\end{array}$ \\
\hline $\begin{array}{l}\text { Tila Fish } \\
\text { Limited }\end{array}$ & $15 / 11 / 2007$ & Senchi & Er & China & $\mathrm{Jv}$ & Agric & $\begin{array}{l}\text { Fish } \\
\text { Farming }\end{array}$ \\
\hline $\begin{array}{l}\text { JiaHuaAgric } \\
\& \\
\text { Technology } \\
\text { Company } \\
\text { Ltd }\end{array}$ & $18 / 01 / 2010$ & Tema & $\mathrm{Gr}$ & China & $\mathrm{F}$ & Agric & $\begin{array}{l}\text { Farming } \\
\text { of } \\
\text { Vegetable } \\
\mathrm{s}\end{array}$ \\
\hline $\begin{array}{l}\text { Agriculture } \\
\text { Technology } \\
\text { Developmen } \\
\text { t Ltd }\end{array}$ & $05 / 02 / 2010$ & Tamale & $\mathrm{Nr}$ & China & $\mathrm{F}$ & Agric & $\begin{array}{l}\text { General } \\
\text { Agric, } \\
\text { Import } \\
\text { and } \\
\text { Export } \\
\text { OgAgric } \\
\text { Machiner } \\
\text { y, } \\
\text { Manufact } \\
\text { uring } \\
\text { AgricEqpt } \\
\text {, }\end{array}$ \\
\hline $\begin{array}{l}\text { Infinity } \\
\text { Company } \\
\text { Limited }\end{array}$ & $05 / 02 / 2010$ & Tamale & $\mathrm{Nr}$ & China & $\mathrm{F}$ & Agric & $\begin{array}{l}\text { General } \\
\text { Agric, } \\
\text { Import } \\
\text { and } \\
\text { Export of } \\
\text { Agric } \\
\text { Machiner } \\
\text { y, } \\
\text { Manufact } \\
\text { uring } \\
\text { AgricEqpt } \\
\text {, }\end{array}$ \\
\hline $\begin{array}{l}\mathrm{Hu} \quad \mathrm{Nan} \\
\text { Farms } \\
\text { Limited }\end{array}$ & $17 / 05 / 2010$ & Afienya & $\mathrm{Gr}$ & China & $\mathrm{Jv}$ & Agric & $\begin{array}{l}\text { General } \\
\text { Farming. } \\
\text { Company } \\
\text { Will Grow } \\
\text { Variety of } \\
\text { Vegetable } \\
\text { sand }\end{array}$ \\
\hline
\end{tabular}




\begin{tabular}{|c|c|c|c|c|c|c|c|}
\hline & & & & & & & $\begin{array}{l}\text { Rearing } \\
\text { Pigs }\end{array}$ \\
\hline $\begin{array}{l}\text { Gya Glorify } \\
\text { Farms } \\
\text { Limited }\end{array}$ & $16 / 11 / 2011$ & $\begin{array}{l}\text { Dentsaw } \\
\text { orme }\end{array}$ & $\mathrm{Vr}$ & China & $\mathrm{Jv}$ & Agric & $\begin{array}{l}\text { Gen. } \\
\text { Farming, } \\
\text { Aquacultu } \\
\text { re Fish } \\
\text { Farming }\end{array}$ \\
\hline $\begin{array}{l}\text { China Fujian } \\
\text { Fishing (Gh) } \\
\text { Ltd. }\end{array}$ & $22 / 03 / 2016$ & $\begin{array}{l}\text { Akosom } \\
\text { bo }\end{array}$ & Er & China & $\mathrm{F}$ & Agric & $\begin{array}{l}\text { Fish } \\
\text { Farming }\end{array}$ \\
\hline
\end{tabular}

Source: Ghana Investment Promotion Authority (GIPA), 2017

$$
\begin{array}{cc} 
& \text { Within a period of twenty } \\
\text { years } \quad(1997-2016), \quad \text { fifteen }
\end{array}
$$
companies had been registered in Ghana for agricultural purposes. These companies were either fully owned by Chinese companies or by a joint venture between Chinese and Ghanaian business enterprises. From Table 2, having fifteen registered companies within a period of 20 years suggests that the agricultural sector records an average of less than one Chinese company. It is apparent in the data that, as at 2014, the agricultural sector had recorded fourteen registered companies with the GIPA inching up to 15 in 2016. Moreover, in 2013 when a total of 219 with an estimated investment value of US\$259.56 million had registered in Ghana (GIPC, 2013) none of these went into the agricultural sector. Below is a pictorial representation of the narratives afore-mentioned. 


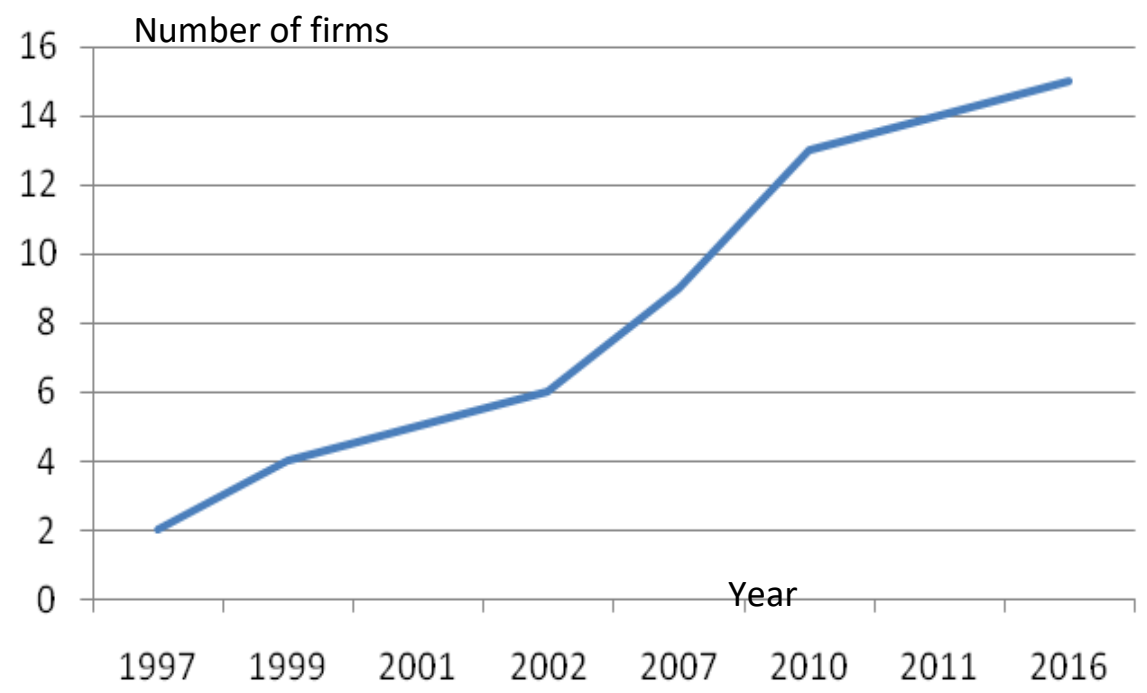

Figure 1: Chinese Investment in Ghana Agricultural Sector (1997 - 2016) Source: Author's own construction from GIPA, (2017).

The low patterns of shown in Table 3. By the first capital mobility are not different from the generally low patterns of quarter of 2017 the following was capital mobility into Ghana's the nature of capital mobility in agricultural sector foreign direct terms of FDI into Ghana's investors from other countries, as economy, among the sectors.

Table 3: FDI in Ghana as at First quarter of 2017

\begin{tabular}{|c|c|c|}
\hline Sector & Number of Projects & Amount Invested \\
\hline Manufacturing & 13 & 2.5 billion \\
\hline Service & 12 & 10.62 million \\
\hline General Trading & 10 & 15.87 million \\
\hline $\begin{array}{l}\text { Building and } \\
\text { Construction }\end{array}$ & 5 & 6.4 million \\
\hline Agriculture & 1 & 6.91 million \\
\hline
\end{tabular}

Source: Authors' own construction from GIPA, (2017). 
It is thus clear from Figure 1 and Table 3 that the attraction of Chinese investment into the land-based agricultural sector has not been encouraging. This situation is not different from general trends on the African continent. Indeed, this finding corroborates previous findings by Brautigam and Ekman (2013) and Brautigam and Zhang (2013) that, in Africa, there are far fewer landbased investments than media houses have reported. This raises issues of policy and favorability of the investment environment in the agricultural sector. As it stands, there are conditions which dissuade investors from investing in land-based agriculture. Generally, these are macro issues which relate with lack of infrastructure, distance to markets (see Scoones et al., 2016) and the decentralized and traditionallybased land tenure administrative structure (Boamah, 2014; Schoneveld \& German, 2014). In spite of lower levels of land-based agricultural investments, Chinese capital mobility into the agricultural sector, as indicated, represents an apparently diverse array of engagement in that sector including activities such as general agriculture, tuna fishing, aquaculture, vegetable farming, poultry production and the distribution of agricultural machinery and agro-processing equipment. Table 4 shows the number of Chinese investments in the subsectors in the agricultural sector which has attracted Chinese capital mobility. 
Table 4: Agricultural Subsectors Attracting Chinese Capital Mobility between 1997 and 2016

\begin{tabular}{lc}
\hline Subsector & FDI \\
\hline Fish farming and Aquaculture & 5 \\
Vegetable production & 4 \\
Poultry production & 3 \\
General Agriculture & 3 \\
Trade of and Manufacturing of Agricultural & 2 \\
Machinery & \\
Tuna Fishing & 1 \\
Rearing of Pigs & 1 \\
\hline
\end{tabular}

Source: Authors' own construction from GIPA, (2017).

The predominantly primary-based nature of Chinese investment in the agricultural sector corroborates Amanor's (2013) finding which indicates that China does not yet have significant agribusiness companies operating in the agricultural sector with just a number of small Chinese farmers operating in Ghana producing vegetables, cowpeas and Jathropha while some of these farmers are also involved in distributing Chinese agricultural machinery. This also raises policy issues and perhaps may lend credence to the widely held impressions by Chinese critics that Chinese presence in Africa is focused largely on natural resource extraction and manufacturing. It must also be noted, perhaps to buttress the arguments of the critics that Chinese subsidiary in Ghana, known as Wynca Sunshine (Ghana) Agric Products and Trading Company Limited has been engaged in the production of agro-chemicals. The brand name for the company's agro-chemical products is Wynca. Wynca Sunshine (Ghana) Agric Products and Trading Company Limitedis engaged in the production of herbicides such as Rezim and Caritek as well as insecticides including Sunpyrifos and Lamdakin. 
With the data obtained, it is also plain that unlike the discovery made by Brautigam and Tang (2013) about an interest in contract farming arrangements for key crops (including cotton and tobacco) in Africa, this observation cannot be held applicable to Ghana since the Chinese investment into the agricultural sector has not yet entered into key crops, particularly the cocoa subsector, as the data on the profile of Chinese companies engaged in Ghana's agricultural sector from GIPA (2017) suggest.

Capital Mobility in Ghana's Fisheries Subsector: A Focus on the Fish Trawling Industry

In Ghana, the fisheries subsector consists mainly of marine fishery, inland (fresh water) fishery and aquaculture fishery and other related activities such as fish storage, preservation, marketing and distribution (GIPA, 2015).

The fisheries sector's contribution to national economic development is evident in an estimated $3 \%$ of the total GDP and $5 \%$ of the GDP in agriculture. In terms of employment the fisheries sector employs $10 \%$ of the country's population (GIPA, 2015).

Notwithstanding the fact that land-based investment has been low with just about five of the fifteen in the fish farming and aquaculture industry, a significant amount of investment could be seen in the marine fishing sector, albeit largely limited to the fish trawling industry. A structural profile of the marine fisheries industries will provide an understanding to this phenomenon. The marine fishing industry in Ghana can be categorized into four according to the nature of activity carried out. They include the artisanal, semiindustrial (inshore sector), industrial (deep sea) and tuna fleets. Marine fisheries account for over $80 \%$ of the fish consumed in Ghana. It has been realized, however, that fresh water fisheries including aquaculture is considerably increasing thereby contributing a share of the supply and consumption trends (GIPA, 2015).

Regarding tuna fishing, it has not attracted many Chinese enterprises because most of the 
foreigners engaged in fish farming are largely South Koreans. The Tuna sector is about 98-99\% Korean involvement (Ministry of Fisheries and Aquaculture, 2015). Chinese investment in the Tuna sector represents just $1 \%$ of the total investment (Ministry of Fisheries and Aquaculture, 2015). Indeed, the Koreans were present in the fish trawling industry but moved away. In lieu of the fact that the Koreans had moved away from the trawling sector the Chinese took over.

Unlike the semiindustrial fish trawling sector, the artisanal fishing sector rarely attracts Chinese capital mobility. It is so because in Ghana about $90 \%$ of the outboard motors used by actors in the artisanal sector are YAMAHA and SUZUKI brands which are made in Japan. A few items such as the hook and the nylon lines originate from China thus contributing insignificantly to the Chinese capital mobility enterprise in Ghana. The attention is thus restricted to the fish trawling industry given the visible and ostensibly exclusive Chinese engagement in it. The dynamics of the Chinese engagement are as follow:

Interviews carried out at the Fisheries Commission indicate that ownership of a trawling company in Ghana is, by law, exclusively Ghanaian. However, the reality on the ground is that owing to lack of the ability on the part of Ghanaians to raise the needed capital of about $\$ 4$ million to own a vessel they acquire the license to engage in trawling and partner a Chinese who has the financial wherewithal to acquire the vessel for them to operate together. Thus, the trawling sector is about $100 \%$ Chinese holding in terms of vessel purchase financing, hence their engagement in that sector. In terms of crew it is also heavily dominated by Chinese at the top management positions.

Currently, the main player in the fish trawling industrial sector includes the bottom trawlers who generally operate with a depth of up to $30 \mathrm{~m}$ Length Overall (LOA). The industry's main target species include sparids, groupers, cuttlefish and snappers. Between 2008 and 2013 an increase in 
fishing capacity was observed, mainly due to the importation of additional vessels (Ministry of Fisheries and Aquaculture, 2015). In 2014, the fisheries sub-sector comprised 107 active vessels which contributed to an estimated annual catch of nearly 20,000 tonnes (Ministry of Fisheries and Aquaculture, 2015).

However, interviews at the Fisheries Commission indicated that some of the vessels had been operating in a very poor state, hence the Commission removed them from the fisheries register which resulted in substantial reduction in fishing effort with the implementation of the Fisheries Management Plan (2015-2019). As at 2017, the register of vessels had records of 80 active vessels and each vessel costs an average of US\$4 million totaling an estimate US\$320 million as at 2017. Despite the reduction, in the number of vessels, there was an increase in the quantity produced from 20,000 tonnes in the years prior to 2015 to $53,100.30$ in 2015 largely attributable to the sizes of the vessels and their technical efficiency. However, between
2015 and 2016 there was a slight increase of 650.01 tonnes in the quantity of fish produced.

The Neo-Liberal Context and Political Economy Heterodoxies to Chinese Investment in Agricultural Sector

It is evident from the data that Chinese capital mobility in the agricultural sector can be largely found in the Tuna farming, vegetable production and poultry production, and fish trawling industries. It will be equally useful to point out that contrary to Mueller and Mueller's (2014) argument that China's increasing reliance on food and feed imports from Africa is directed at satisfying her growing demand, Ghana's case is an exception. Judging from the industries where the Chinese investments into the agricultural sector are being directed into, it could, by and large, be understood within certain micro economic contexts. In the first place, the attraction of Chinese capital mobility into the vegetable production arena has been motivated by the need to meet the dietary needs of a growing number of Chinese nationals engaged in varied forms 
of economic activities who patronize restaurants and shops serving Chinese meals (see Cook, Tugendhat \& Alemu, 2016).

In terms of poultry production, it has also gained Chinese capital mobility attraction because of the increasing demand for poultry products evident in the increased importation of poultry products. Clearly, the attraction of Chinese investments has been largely motivated by an increasing demand in the products offered by Chinese investors. These rationalizations support the argument by Harvey (1975) that MNEs are attracted to host countries that will enable them have value for their financial capabilities ranging from their sales efforts to reduced turnover time on fixed capital. However, despite the Chinese presence in the poultry industry, the import levels are rising. As indicated on Table 6 the quantum of imports rose from 120,000 tonnes in 2015 to 165,000 tonnes in 2017.

Table 5: Production and consumption and imports of poultry into Ghana (, 000 tonnes)

\begin{tabular}{llll}
\hline Year & Consumption & Local Production & Imports \\
\hline $\mathbf{2 0 1 5}$ & 175 & 55 & $\mathbf{1 2 0}$ \\
$\mathbf{2 0 1 6}$ & 205 & 55 & $\mathbf{1 5 0}$ \\
$\mathbf{2 0 1 7}$ & 221 & 56 & $\mathbf{1 6 5}$ \\
\hline
\end{tabular}

Source: Ashitey, (2017)

Hence, even though there is a level of local demand the investment has been low. Evidently (see Table 2) the last time a Chinese company entered the poultry industry was in 2001 . Clearly, the local conditions are not favorable for investment in the poultry industry. Consequently, the local producers and Chinese producers mentioned the market prices of local broiler meat are inclined to be higher than imported one. This corroborates Ashitey's (2017) observation that the price of local broiler meat 
tends to be higher than imported meat by $30-40$ percent margin, making local broiler meat uncompetitive.

Despite the low levels of investment, an examination of the patterns of distribution of Chinese investments across the sub sectors and the geographical areas clearly suggests that the sub sectors which are receiving attraction are areas with expanded markets. The Chinese are, by virtue of rational actions, responding to market demands in the agricultural sector. Beyond the economic motivations of the Chinese, the availability of naturally endowed resources suitable for certain types of agricultural activities. While the availability of water bodies creates the ecological environment of fishing the arable lands are suitable for vegetable production. This then shows that capital mobility may be driven by the availability of natural resources in the geographical area where capital is attracted to.

Apart from the specific rationalizations, it is also evident that the ecological conditions expressed through the availability of certain natural resources could equally serve as sources of attraction of Chinese into Ghana's agricultural sector. This supports Storper's (1997) assertion that the emergence of a 'regional world' is essentially underpinned by the spatially-bounded localized forces, which are natural in essence. This is clearly showed on Table 6.

Table 6: Regional Distribution of Chinese Investment into the Agricultural Sector

\begin{tabular}{lll}
\hline Region & $\begin{array}{l}\text { Number of Companies } \\
\text { in the Agricultural } \\
\text { Sector }\end{array}$ & $\begin{array}{l}\text { Types of Agricultural } \\
\text { Activity }\end{array}$ \\
\hline & & $\begin{array}{l}\text { Fish farming and } \\
\text { aquaculture, poultry } \\
\text { farming, tuna fishing, } \\
\text { vegetable farming, pig } \\
\text { farming }\end{array}$ \\
\hline Greater Accra & 9 &
\end{tabular}




\begin{tabular}{lcl} 
Northern & 2 & $\begin{array}{l}\text { Trade and manufacturing } \\
\text { of agricultural machinery } \\
\text { Vegetable production and } \\
\text { fishing }\end{array}$ \\
Eastern & 2 & Fish farming \\
\hline
\end{tabular}

Source: Authors' own construction from GIPA, (2017)

It is apparent from Table 6that Chinese investment into the agricultural sector is concentrated in only four out of the ten regions of Ghana. Out of the four, there is a heavy concentration of the investments in the Greater Accra Region. The region has 9 out of the 15 companies. The 6 remaining investments are evenly spread among the Northern, Volta and Eastern Regions with 2 companies each.

This demonstrates that the capital mobility patterns from China into Ghana's agricultural sector are skewed in favor of the Greater Accra Region. However, a closer look at the activities carried out in the various regions show that activities such as fish farming and vegetable production are equally being carried out in other regions such as Volta and Eastern Regions. This indicates that the attraction for investment is not only by virtue of the natural resources which are suitable for certain kinds of agricultural activity but by virtue of availability of infrastructure.

These ecological-
oriented
notwithstanding, the picture about the location of Chinese investment is not limited to the availability of natural resources alone. It is visible that the geographical distribution of the Chinese investment in Ghana is a function of economic triggers such as market demands and infrastructural development and incentive conditions which correlate with the location of Chinese investment in Ghana's agricultural sector.

Appealing to the essence of political economy heterodoxy there are more conditions that will determine where an investment will be sited. Indeed, the Ghana Investment Promotion Authority has acknowledged this reality and 
has thus introduced some tax incentive packages for business. However, the result after these incentive packages, have been the skewed geographical patterns of Chinese investment in the various regions of Ghana. Looking at the actual location in the Greater Accra Region where majority of the Chinese investments in the agricultural sector could be found they are actually located at Tema which has all the infrastructural facilities such as the Tema Port and the roads. This is where the harbor is located hence the investors' quest to take advantage of proximity in order to reduce cost of transport influence them to site their investment locations in Tema. This resonates the assertion that improved economic infrastructure such as development of transportation and communication systems may influence the pace at which capital mobility would eventually affect regional economic development process (Marx, 1967; Rodrigue \& Notteboom, 2017).

In the fisheries subsector, the level of investment is rationally motivated by the fact that there exists an appreciable market for fish and fish products. This is clearly elucidated by the Ministry of Food and Agriculture (2015) that fish remains the main and preferred animal protein food for Ghanaians with about 75 percent of the total domestic production of fish is consumed locally. The high local demand for fish is coupled with an appreciable demand for exports at the international markets to attract Chinese investment in the fish trawling sector. A financially unsupportive economic regime which makes it difficult for Ghanaian to raise capital and a flexible legal regime which allows Ghanaians to operate in partnership with foreign investors explains the high Chinese investment in the industrial fishing sector.

$\mathrm{XForms}$ and trends of Capital Mobility from China into Ghana's Agricultural Sector: Trade

Capital mobility is accountable for the nature of items being spread on the altar of globalization. On this score the quest to establish how trade promotes capital mobility from China to Ghana's agricultural 
sector becomes critical. Capital mobility in the agricultural sector through trade, for the sake of this analysis, is categorized into the agricultural sub sectors namely crop production and animal husbandry. This is to enable comparisons in trade in agricultural sector between the sub sectors to help shape traderelated agricultural policy.

It will be instructive to note that there are many other agricultural inputs from China into Ghana's animal production subsector. In the course of the data collection it was discovered that poultry feed supplement such as Joyvet and Ampivite were on the Ghanaian market for sale. This was because the importers of these products started importing them in 2017. Figure 2 gives a composite view of the value of imported agricultural inputs from China into Ghana agricultural sector.

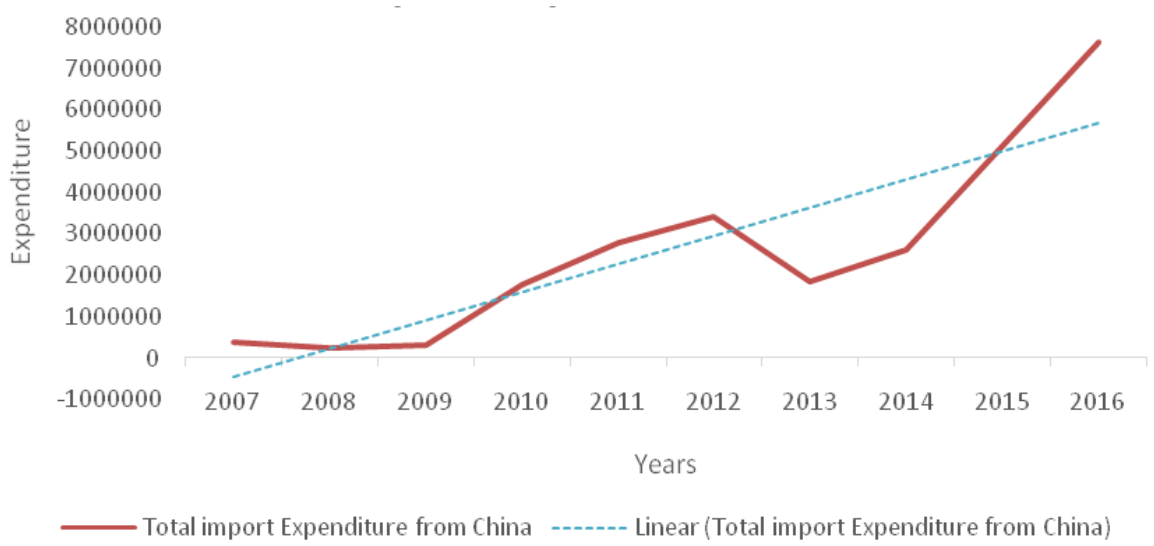

Figure 2: Agricultural Inputs Imported from China into Ghana's Agricultural Sector

Source: Authors' own construction from Ministry of Trade and Industry, (2017)

Figure 2 shows an

$\mathrm{GH} \not 230,286.9$

and

expenditure of $\mathrm{GH} \phi 369,379.8$ in

$\mathrm{GH} \phi 298,286.9$ in 2008 and 2009, 2007. This figure dropped to respectively. In 2010, however, 
the import expenditure increased over five times to $\mathrm{GH} \notin 1,769,731$. Since then the expenditure had been increasing over the years up to 2016 when it reached the tune of $\mathrm{GH} \phi 7,647,556$, despite some noticeable drops in the expenditure from $\mathrm{GH} \notin 3,412,071$ in 2012 to $\mathrm{GH} \phi 1,839,130$ in 2013. It can be inferred from the data that, on the average, Ghana had spent an amount of $\mathrm{GH} \notin 2,609,904.424$ to import agricultural input from China, annually. The trend also represents an average year-onyear increase between 2007 and 2016 of $\mathrm{GH} \phi 727,817.64$ representing an average rate increase of 43.3 percent, yearly. This trend shows that the rate of influx of Chinese agricultural input increased at a high pace, especially between 2014 and 2016 given the fact that the trend exceeded the average rate of increase. A breakdown of this aggregate import into the crop and animal husbandry sub sectors are as follow

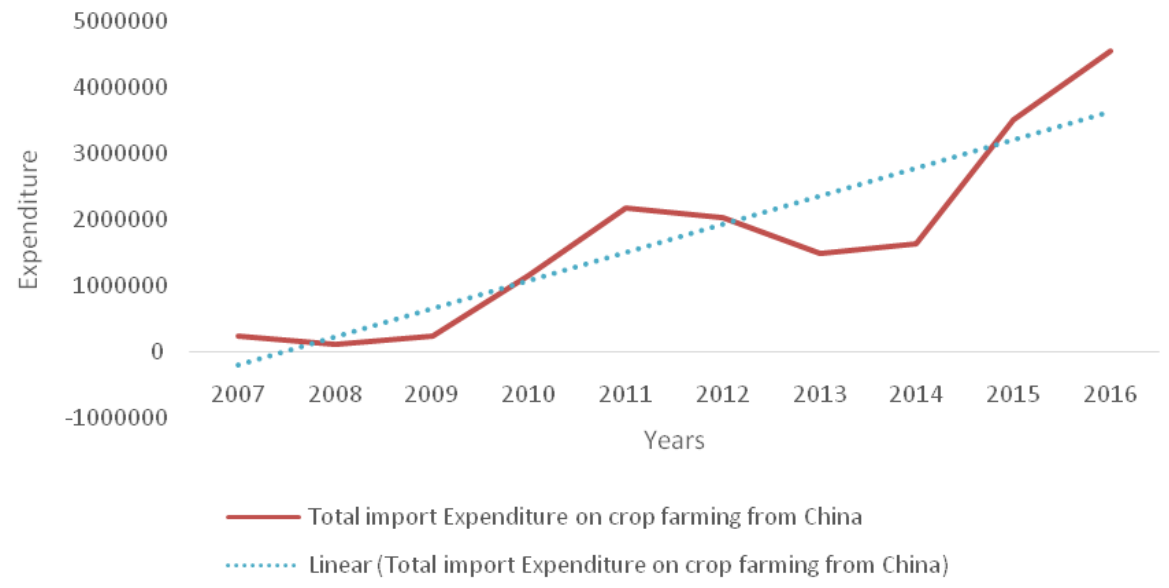

Figure 3: Agricultural Inputs Imported from China into Ghana's Crop Sub Sector

Source: Authors' own construction from Ministry of Trade and Industry, (2017) 
The import expenditure on input into the crop farming from China shows an amount of $\mathrm{GH} \notin 242,364.2$ in 2007. This figure dropped to $\mathrm{GH} \phi 118,810.79$ in 2008 but increased to $249,613.50$ in 2009. The import expenditure then increased significantly to $1,161,564.40$ in 2010. Since then the expenditure level increased significantly over the years up to 2016 when it reached the tune of $\mathrm{GH} \phi 4,548,626.41$, despite some noticeable drops in the expenditure from $\mathrm{GH} \phi 3,412,071$ in 2012 to $\mathrm{GH} \phi 1,839,130$ in 2013. It can be inferred from the data that, on the average Ghana had spent an amount of $\mathrm{GH} \notin 1,716,199.04$ to crop farming input from China, annually. The trends denote an average year-onyear increase between 2007 and 2016 of $\mathrm{GH} \phi 430,626.21$ representing an average rate increase of 63.29 percent, yearly. This trend shows that the rate of influx of Chinese agricultural input is increasing at a high pace, especially between 2013 and 2016.

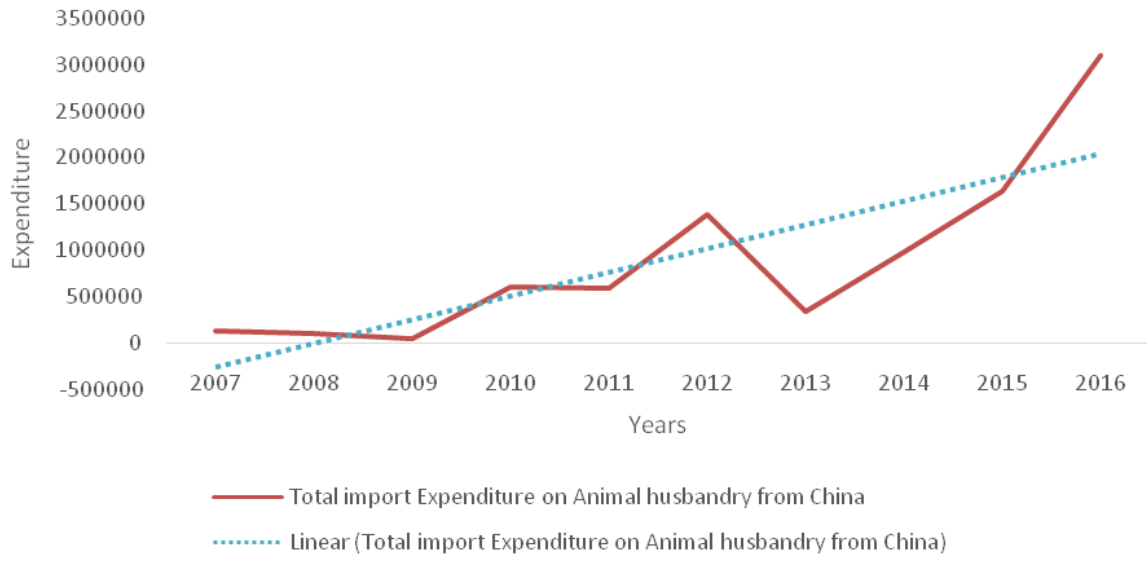

Figure 4: Agricultural Inputs Imported from China into Ghana's animal husbandry Sub Sector

Source: Authors' own construction from Ministry of Trade and Industry, (2017) 
The agricultural input import trends in the animal husbandry industry show an expenditure of $\mathrm{GH} \phi 127,015.57$ in 2007. This figure dropped to $\mathrm{GH} \phi 111,476.08 \quad$ and GH $\not 49,195.43$ in 2008 and 2009, respectively. In 2010, however, the import expenditure appreciated over the 2009 figure to $608,166.30$. Even though it dipped to 589164.81, in 2011 it appreciated to 1385636.26 in 2012. The import pattern remained undulating till it reached a peak of 3,098,929.76 in 2016. It can be thus be established from the data that, on the average, Ghana had spent an amount of
$\mathrm{GH} \not \subset 893,705.38$ to import animal husbandry inputs from China, annually, between 2007 and 2016 . The trend also denotes an average year-on-year increase between 2007 and 2016 of GH $\varnothing 297,191.42$, representing a yearly average increase of 146.45 percent. This trend shows that the rate of influx of animal husbandry input also increased at a high pace, especially between 2014 and 2016 just like the total Chinese agricultural input. A summary of the average spending and the yearly average increase are shown on Table

Table 7: Average spending and the rate of increase (2007-2016)

\begin{tabular}{lll}
\hline Subsector/Sector & $\begin{array}{l}\text { Average Yearly } \\
\text { Spending (GHS) }\end{array}$ & $\begin{array}{l}\text { Yearly Average Spending } \\
\text { Increase (\%) }\end{array}$ \\
\hline Crop & $1,716,199.04$ & 63.29 \\
Animal Husbandry & $893,705.38$ & 146.45 \\
\hline Agricultural Sector & $2,609,904.424$ & 43.3 \\
\hline
\end{tabular}

Source: Authors' own construction from Ministry of Trade and Industry, (2017).

The Neo-liberal Side of the Patterns of Imports of Chinese Agricultural Inputs

Before we situate the agricultural-related import patterns from China to Ghana within neo-liberal contexts it will be important to recognize that the influx of Chinese equipment in Ghana is a reflection of a general 
trend in Africa where trade in agricultural commodities have largely included processing machinery and input supply which, according to Kaplinsky (2013), represents a potential for investment along agricultural value chains. This also echoes the political economy perspective to capital mobility adduced by Agyei-Holmes (2013) who argues that the transfer of technology from China to Africa succeeds where there is a clear demand.

Over the years Ghanaian agricultural actors are becoming attracted to Chinese products. Interviews with some of the meat processors, for example, indicate such key examples of Chinese products as vacuum sealers, temperature controllers and bone saws. In the first place, the high rate of influx of Chinese agricultural inputs can be explained by making reference to Kang's (2015) argument that the flow of capital as expressed in technology transfer increases when the technological portfolios of two countries are not similar. Hence, the high rate of influx of Chinese agricultural inputs is a function of an asymmetrical technological relationship between China and Ghana. Generally, Ghanaians in the agricultural sector are attracted to some Chinese agricultural inputs because there are no local substitutes for some of these inputs. This was clearly elucidated in the responses of two of the research participants (an aqua culturist and a meat producer) who argued that the absence of local substitutes for some Chinese agricultural inputs is a reason for which they imported Chinese goods. An aqua culturist, for example, indicated that

"we'll go to China
because when you look
for local substitutes you
don't get".

The influx of the Chinese agricultural input is attributed to the growing number of distributors of Chinese agricultural input. Interviews with the Agricultural Engineering Services Directorate showed that there are a number of private firms engaged in the importation of Chinese agricultural inputs. Notable private distributors include Motorking Company 
Limited and RST Company Limited. But within broader economic contexts, has been largely due to macroeconomic policies such as trade liberalization and privatization being pursued in Ghana. These issues affirm the arguments of Scoones et al. (2016) who noted that the rise of China's involvement in African agriculture with the flow of capital has coincided with the restructuring of most African economies with the introduction of neo-liberal economic policies.

It is enlightening, albeit, to note that even though this has been facilitated by certain macroeconomic policies such as trade liberalization, the proliferation of the virtual trading platforms, the Chinese products remain attractive to actors in the Ghanaians agricultural sector because of a number of reasons born out of the actors' experiences. One of the key reasons has been the high visibility of Chinese products on online platforms made possible by technological advancement expressed in the advent of the information technology.
The evidence of the role of the virtual platforms in facilitating the influx of Chinese agricultural inputs was gathered when actors were made to convey complex knowledge through their stories about their use of Chinese agricultural products, and not merely their opinions. A meat processor who maked special mention of one of the online platforms known as 'Alibaba' said,

“We've imported a few thing,s which all go to the smoking business, and whenever we need an item, we source the country to compare and whenever we don't get what we want then we go and browse. There's everything on Alibaba. We go there trusting quality because Alibaba has its own quality checks and security checks. So, we do it, once you go to Alibaba it means you can complain to Alibaba, and the peoples their business 
is more important to them and their quite sincere".

This response makes it apparent that technological changes have revolutionized the trade patterns making it equally interactive and efficient even on virtual platforms and thus reinforcing Rodrik's (2011) assertion that technology plays a role in promoting economic activities.

But it will be instructive to note, perhaps indisputably, that in an arena where trade liberalization is encouraged and practiced, the issue of price falls at the epicentre of trade actors. Upon the interviews conducted it was discovered that the cost of the Chinese agricultural inputs served as a centripetal force to patronage among Ghanaians in the agricultural sector.

A key element in the understanding of the increasing level of patronage of Chinesemade agricultural input is the price factor which remains one of the basic foundations upon which economic actors compete in any liberal order. In the arena of neoliberalism, this economic variable remains key in all business endeavours. In the course of the interviews, such an economic variable played out in the patterns of import of Chinese agricultural input. Indeed, the officials in state institutions and actors in the agricultural sector provided a unison response in this regard. A meat processor in Ghana's agricultural sector, for example, referred to one of the equipment he had acquired from China to indicate that some Chinese products are relatively cheaper than the locally produced equipment in Ghana. He revealed it as follows:

"We tried looking for VACUUM SEALERS here the value is like 10,000 Ghana cedis. You get the same equipment from China at about...if you add duties and everything together; it doesn't go like beyond 3000".

With regard to crop farming agricultural machinery imported from China, the cost factor played out visibly. As was mentioned by officials in the 
Agricultural Engineering Services Directorate when they were asked why Chinese agricultural inputs are preferred,

"Of the top of my head I will say cost. Personally, it will be difficult to say that they Chinese ones were not good or they were good but at least what in know is that theirs is always the cheapest in most cases and that makes it attractive to people"

The cost factor which occasioned the preference for crop farming agricultural input was corroborated by engineers of the Agricultural Engineering Services Directorate. One of them said "It is nothing but the low cost of Chinese machinery which has made Government of Ghana accept to allow
Chinese machinery to be imported"

The importer of Chinese livestock drugs maintained the same position as he points out that

"The China drugs appear to be cheaper but effectively they are same. They all serve the same purpose".

Then regarding the crop farm agricultural equipment too, an official of RST, importer of Chinese agricultural equipment, indicated, in a similar fashion, that:

Examples to buttress this claim are as follow: 
Table 8: Price Differentials between Chinese and Indian made agricultural inputs, 2018

Equipment (GHC)
Price of Chinese origin Price of Indian origin $(\mathbf{G H} \boldsymbol{c})$

\begin{tabular}{lcc}
\hline Rice Thresher & 17,000 & 21,000 \\
Multi-purpose & 11,000 & 23,000 \\
Thresher & &
\end{tabular}

Source: Authors' own construction from RST, (2017).

She went on further so say that

"We [RST] have a
power tiller one is from
Vietnam and one is
from China; the China
one is complete with the
trailer, cage wheels
with the head is
GH 20,400 and for the
Vietnam one only the
head without trailer is
GH $23,000 "$

It will be instructive to establish that even though all the respondents made mention of the relatively lower prices of Chinese agricultural input there was no consensus about whether the lower prices were coterminous with product efficiency. From the answers, some of the respondents maintained that relatively lower prices were equally a guarantee for high quality and value for money. For example, the meat processor interviewed hinted that

"They'll give you
equipment that
consumes less
electricity and,
equipment that is
within your budget"

Another
participant, an aqua culturist,
engaged in tilapia hatchery,
responded in a similar fashion. His
response was suggestive of the
fact that Chinese agricultural
inputs give value for money. He
mentioned that:

"They take you along in their system of development and productivity". 
Some of the respondents, however, acceded to the reality that the relatively lower-priced Chinese agricultural input was rather matched with a relatively lower level quality. Referring to the quality of poultry drinker, the importer of Chinese poultry inputs who also started importing Italian made poultry equipment maintained that.

"Actually, doing a comparison of the Chinese and the Italian equipment the Italian ones appear to be more durable when you feel the texture but there is also a price difference; the Italian one is 25cedis while the Chinese one is GH\&20".

In this regard, a price difference of about $\mathrm{GH} \phi 5$ relative to the quality difference was discovered. The RST official also mentioned that

"but the quality of the Chinese equipment is not like the other countries". The quality of the other countries is better than what comes from China",

Despite the absence of uniformity in the respondents' experiences which occasioned the quality of the Chinese agricultural inputs, one observation stands out; beyond doubt, these responses generally confirm the political economy perspective held by Agyei-Holmes (2013) about Chinese trade which holds the contention that in Africa the transfer of technology from China to Africa succeeds where there is a low cost.

It must, however, be emphasized that even though it has been mentioned in earlier sections of this analysis that actors in Ghana's agricultural sector are attracted by relatively low prices of Chinese products it is not applicable to all agricultural inputs. Indeed, some of the agricultural inputs from China were found to be relatively expensive than the local substitutes and that served as a deterring condition for the patronage. 
Ironically, one of the key issues which emerged in the course of the research was also hinged on the issue of cost. In the first place there were some other products or Chinese origins which have relatively higher prices. A typical example that could be drawn in this regard was gathered from a meat processor who shared his experience when he decided to purchase a Chinese oven and Chinese pork packaging polythene from China. With regard to the Chinese oven, he said

"we have sailing machines from China, you know, they have smokers, ovens, we haven't bought the oven because we felt it's a expensive so the local oven that is what must be interesting to know. Their offer for oven was 6000 dollars as against a local not too good one for 2000".

Regarding the pork packaging polythene, he narrated his experience as follows "later on, we imported some of their polythene sheets at the end of the day when we calculated it, we saw that it was expensive but the same sum we had we've been able to source".

This issue of high cost supports the observation made by Chichava, Duran, Cabral, Shankland, Buckley, Tang, and Yue (2013) that some technology transfer programmes were challenged by farmers' inability to pay for services associated with the technology.

Given the role of cost as an attractive and deterring factor it will be crucial to emphasize that the role of the cost is largely determined by the type of product. Nevertheless, the observation made about the cost being a discouraging force in the patronage of Chinese products may smack off rationality of the Ghanaian agricultural actors at the micro level.

However, beyond the purely economic issues including demand and prices as key correlates of the attraction to Chinese agricultural inputs, there 
are other issues which appeal to heterodox political economy which equally account for the attraction.

The Social Innovative Side of the Capital Mobility: Attractiveness of Chinese Agricultural Inputs to Ghanaian Agricultural Actors

Suffice to say that apart from the role of neo-liberal macroeconomic and technological advancement the Chinese manufacturing and trading firms have developed some organizational practices which make their agricultural inputs goods more preferable to agricultural products from other countries with details discussed in subsequent sections. These are issues that Agyei-Holmes (2013), Kamplinski (2013), Amanor (2013), Chichava et al. (2013) and Scoones (2016) did not observe nor talked about in their respective studies. Yet, it is important that these issues are brought to the fore because they are of particular interest in political economy heterodoxies. Their main relevance stems from the fact that they serve as foundations for international economic relations and growth and as well as political dialogues and decisions. These issues by and large relate with how the Chinese generally handle their organisational practices and, their customers. These issues are outlined subsequently.

Following are those practices which rendered the Chinese agricultural products attractive as expressed in the responses offered by actors in the Ghanaian agricultural sector who constituted the research participants to this study. They include customer-oriented practices such as timely delivery of products, effective communication mindset by Chinese input suppliers towards Ghanaian agricultural actors, door-to-door delivery and offering customer advice. Others include offer credit facilities, regular training for retailers and regular meeting with farmers.

Their customer-oriented care practices include the following based on the experiences some actors in the agricultural sector have had with Chinese companies in China and Chinese subsidiaries in Ghana, after comparing their experiences 
with the Europeans. For example, one of the respondents, a meat producer said,

"So, at the end of the day it is their culture; I don't get the same feel when I'm talking to Europeans. So, there is a culture bid, the culture of...er Chinese and their attitude to business is down to earth, friendly, thorough so it becomes a good choice".

Beyond the general mode of attraction, the research participants brought out specific practices that attracts them to Chinese agricultural inputs discussed as follow. One of the customer-attractive elements that occasioned the sale of Chinese agricultural products as the myriad categories of actors in the agricultural sector was the fast pace with which the agricultural inputs were delivered. In a fast pace and competitive globalized economic order world where time is regarded as essential in any business endeavour, it was understandable how end users would find this act by Chinese firms a source of attraction. A meat processor, for example, did not mince words about his attraction to Chinese agricultural input on the altar of quick product delivery. He indicated that

"It may take you shorter time to access and take delivery of this equipment and I will tell you how. You lie on your bed, and you go to Alibaba, you browse from company to company with the same equipment comparing prices and looks. Then you can interact with them directly on WhatsApp or whatever means. If you bet by the end of the week the product is in your hand here because the moment you agree you transfer money, it can be by DHL, or through let's say... for us there is a Ghanaian agent in China so they will send the items to him, put it on the next plane and we know where to pick 
it from Accra or how it will be sent to us and we pay for it".

This effort smacks of high levels of competency and commitment as organizational innovation practices on the part of Chinese companies which resonates the ideas of Neumeier (2012). The timely delivery of products generates trust for the Chinese producers thereby enhancing the attractiveness of Chinese capital mobility confirms the arguments of Piore and Sabel (1984) trust is a fundamental requirement for regional economic success in an era of global economic expansion.

Chinese were also observed to be offering an effective method of communication with the end users of their products. This occurred in the context where trade relations between Chinese firms and Ghanaian end users involved virtual platforms. Another meat processor commented on his experience as follows:

"You can even talk on phone which we do and there are people who speak English in every company now in China and they are more courteous and understand more business than some of the people we deal with in Ghana. Chinese and their attitude to business is down to earth, friendly, thorough so it becomes a good choice. Now before I sleep, they are ahead of us 7 hours. When $I$ send $a$ WhatsApp at 10pm here I'll get the response from them instantly. When I send a WhatsApp at 5 am here I'll get the response. So, one day I was asking, don't you guys sleep? You decide on a product tonight, by the following morning you would have decided to order it or otherwise."

From the responses it is quite remarkable to note that the Chinese suppliers exhibited creativity, commitment and competency in their 
communication endeavors by adapting to the learning of the English language coupled with the attitudes of courtesy and empathy as well as a timely response to requests as part of their quest to attract customers. The use of English language as a means of communication by Chinese promoted the degree of social relations between them and the Ghanaian end-users of their products, eventually promoting the attractiveness. This also corroborates Piore and Sabel's (1984) argument that social relations could also serve as a fundamental requirement for regional economic exchanges.

The Chinese have also become well noted for the delivery of products on a door-to-door basis. An agro-chemical retailer expressed his experience as follows

"you know Chinese also what it makes it easy is that they bring it to our doorsteps. They bring vans and things. They have vans and things and they carry it along to supply their goods

unlike

CHEMICO”.

In a post-modern world where comfort and convenience are being sought for by customers the door to door delivery grants leverage to a producer and a service provider over a competitor (see Walker, 1978; Howaldt \& Schwarz, 2010). Just as it was discovered with regard to the effective communication mindset by Chinese input suppliers towards Ghanaian agricultural actors it can be mentioned that the door-to-door model reflects traits of organizational creativity, competency and commitment (Numeier, 2012). Apart from these organizational forms of social innovation by Chinese firms, the deployment of door-todoor- services reflects to role of flexible specialization which, as Piore and Sabel (1984) contend, promotes capital mobility.

The Chinese producers had not made their products attractive by what they sell but they equally enjoyed attraction because they offered technical advice to customers as well. A meat processor shared his experience as in these words 
"you are taught about every item. For example, even selecting the 'BONE SAW', they could tell us no no don't go for this one, this one it heats too quickly. So, if you go for this one, this one is almost like domestic so if you go for this one, it takes longer time for it to heat so don't waste too much time waiting for the equipment to cool"

Such an act of offering advice to customers did not only enable the customer to make rational choices but served as an avenue which latently fed into the knowledge diffusion process because the meat processor, per this experience, gained knowledge about the nature of a product and its suitability for a particular economic activity.

Generally, then, it was apparent that ensuring timely delivery of products, having a communication mindset towards Ghanaian agricultural actors by Chinese input suppliers, offering door-to-door delivery, and offering customer advice were discovered as some of the key customer-oriented practices which gave leverage to Chinese agricultural products over other agricultural inputs. They have exhibited flexible specialization, face-to-face interaction (see Poire \& Sabel, 1984) as well as creativity, collaboration, commitment cooperation and competence (see Numeier 2012; Howaldt \& Schwarz, 2010; Schumpeter, 2004; Pots \& Vass, 2008)

The following are other socially innovative practices that attracted Ghanaian agricultural actors. The data obtained from the interviews also indicated that the Chinese attracted patronage because they offered credit facilities to the end-users of the product. Using WYNCA as a case in point the retailers in the agrochemical industry mentioned in the course of the interviews. The response of one of them is as follows:

"They also give us
credit facilities. But
that is on condition that
the retailer is credit
worthy"


The conditions attached to the credit facilities corroborates Piore and Sabel's (1984) contention that trust, and face-toface social relations are fundamental requirements for regional economic success in an era of global economic expansion. Acknowledging the critical role of retailers in the agrochemical value chain system, Chinese firms, particularly the agro-chemical company, engaged in regular training of retailers. This, according to Chinese firms, happened especially when a new product was introduced. An agrochemical retailer provided a response in support of this claim

"Oh, if there is a new product, they summon us for a meeting then they show us so that we can also do the same thing for the farmers because they have realized that we the dealers the farmers come to us than them".

This practice rested on the assumption knowledge about the availability and the efficacy of products could best be transferred by a retailer among whom farmers have frequent interaction.

This effort indicates competency in terms of knowledge, commitment towards making retailers more efficient as well creating a platform for collaboration and cooperation within which ideas are transferred and the shared.

In addition to the training of retailers, the Chinese agro-chemical company found it necessary to meet the farmers directly. Interpreting this act in the minds of the farmers they mentioned that the regular training played an advantage of generating trust and feelings of respect for them as farmers

"So WYNCA also call you to their place at industrial area. At times too they do visit. ohh...some of these days they arrange with time because mostly they also want to meet farmers directly. So, we do the thing farmers, dealers. We mobilize the farmers and the dealers we all come together. We share 
ideas so some of the problems the farmers are facing concerning the product then they also tell them".

The regular meeting with farmers and regular training for retailers reflect a new and modernized type of entrepreneurial function which emphasises 'cooperation' with other stakeholders including distributors and users of products which has been largely considered as a key organisational efficiency (see Pot \& Vaas, 2008).

Putting all the practices by the Chinese firms together they epitomize organisational innovations which are represented in high forms of dynamic management, skill development and competencies as well as smart work. This confirms Neumeir's (2011) argument that the usefulness organizational endeavours become very visible and attractive since they have a high possibility of creating forms of technical and marketing innovations which could enhance the productive efficiency of the end users of the product.
This observation has also been well adduced by Harvey's (1975) that fast-growing locations are not closed and independent economies, but rather they are, most likely, those area hosting MNEs having financial capabilities ranging from their sales efforts to reduced turnover time on fixed capital and Walker's (1978) argument that technical innovation, organizational change.

\section{Conclusion}

In effect, it is evident that the Chinese capital mobility into Ghana's agricultural sector has been crystallized in forms of FDI and trade. Invariably, the various modes with which capital mobility is crystallized as mentioned is evident and applicable to Ghana as well. Hence, Ghana's naturally endowed resources have rendered it a part of the global economic integration process through capital mobility from China. Not only is Ghana getting attracted to Chinese agricultural business enterprises to engage in protein foods and vegetables but equally remarkable is the supply of a diverse array of Chinese equipment for 
agricultural purposes as well as Chinese agricultural experts.

As it stands, even though Ghana's open economy and the attractiveness of Chinese products by actors in the agricultural sector all of which allow trade in Chinese agricultural equipment to flourish, the Ghanaian economy remains unattractive to land-based agricultural investments and agribusiness from Chinese MNEs having financial capabilities of investing into Ghana's agricultural sector due to infrastructure and land tenure constraints.

Generally, the responses and the analysis so far show that a combination of macroeconomic policies and privatization, trade liberalization and other associated neoliberal essentials such as pricing, increased local demand and absence of local substitutes of Chinese agricultural products have been responsible for the observably increasing pace of the influx of Chinese agricultural inputs into Ghana's agricultural sector.

From the data gathered and the discussions that followed, it is suggestive that beyond macro- \begin{tabular}{lcr} 
economic & trade & policy \\
opportunities & and & $\begin{array}{r}\text { other } \\
\text { opportunities }\end{array}$ \\
offered & through \\
technological & \multicolumn{2}{c}{ advancement, }
\end{tabular} Chinese agricultural inputs remained attractive through some interactive efforts between the Chinese suppliers and the end users found in Ghana's agricultural sector. From political economy perspectives these could be seen as not just echoing the neo-classical argument which regards the interactive efforts as a reflection of the rational and creative methods essential at a sustained capital mobility for China but also as a reflection political economy heterodoxies which appreciates organizational innovation including competency and commitment among the Chinese subsidiaries as well collaboration and cooperation between the Chinese subsidiaries on the one side and the retailers and the end users on the other side. In effect a combination of neoliberal macroeconomic policies, organizational innovation by Chinese firms and technological advancement has fostered the trade-like patterns of capital 
mobility from China to Ghana's agricultural sector.

Thus, capital mobility from China to Ghana's agricultural sector would not have to be understood within neoliberal contexts alone. The capital mobility would also have to be understood within the context of technological advancement and the organizational novelties upon which the agricultural inputs are promoted and spread.

By way of policy, the increasing rate of importation of agricultural inputs from China is an opportunity for knowledge transfer and technological adoption from China and search for less costly local substitutes given the foreign exchange threats on the local currency which constitutes a direct outcome of the importation of the agricultural inputs. This trend means that agricultural development in Ghana would not only largely have to rest on the indigenization of capital investment but with favorable economic conditions.

However, beyond the technological adoption and knowledge transfer dimensions of the policy implications, there is the need to understand the political economy contexts within which the agricultural-input trade and FDI from China take place and draw some lessons in there.

Moreover, it must be emphasized that the influx of Chinese capital mobility, with all the attractiveness, signifies an opportunity for Ghana to take advantage of the patterns of trade and investment and develop the appropriate technology. These could culminate in the production of similar products at relatively cheaper prices. In these regards, the local products would gain a competitive edge over the Chinese products. 


\section{References}

Agyei-Holmes, A. (2013).

Walking the tight rope of tillage technology choice: The peasant's dilemma in the Ubaruku Village of Tanzania.Globelics

Academy Paper, Available at http://www.globelicsacadem y.net/2013_pdf/Full\%20pap ers/Agyei-

Holmes\%20full\%.Accessed

September, 1, 2017.

Aitken, B. \& Harrison, A. (1999).

Do Domestic Firms Benefit from Direct Foreign Investment? Evidence from Venezuela, American Economic Review, 89, (89), 605-618.

Alden, C. (2013). China and the Long March into African Agriculture, 16-21.

Almeida, P. \& Kogut, B. (1999). Localization of Knowledge and Mobility of Engineers in Regional Networks, Management Science, 45, (7), 905-917.

Amanor, K. (2013). South-South cooperation in Africa: Historical, geopolitical and political economy dimensions of international development. IDS Bulletin, 44, (4), 20-30.

Amanor, K. S \&Chichava, S (2016) South-South Cooperation, Agribusiness, and African Agricultural Development: Brazil and China in Ghana and Mozambique, World Development, $11,13-23$. Asamoa, A. K. (2001). Depeasantization of Africa's Rural Economy: The Ghanaian Experience, Woeli Publishing Services, Accra.

Ashitey, E. (2017). 2017 Ghana Poultry Report.Global Agricultural Information Network, USDA Foreign Agricultural

Services.Available at http://eprints.lse.ac.uk.Acce ssed $12^{\text {th }}$ October, 2015.

Ayres, L., Kavanaugh, K. \&Knafl, K. A. (2003) Within-Case and Across-Case Approaches to Qualitative Data Analysis, Qualitative Health Research, 13, (6), 871-883.

Bitzer, J. \&Geischecker, I. (2006). What Drives Trade-related R\&D Spillovers and 
Growth? Economics Letters, 85, 209-213.

Boamah, F. (2014). How and why chiefs formalise land use in recent times: The politics of land dispossession through biofuels investments in Ghana. Review of African Political Economy, 41, (141), 406-423.

Brautigam, D. \&Xiaoyang, T. (2012). An Overview of Chinese Agricultural and Rural Engagement in Tanzania, IFPRI Discussion Paper, Development Strategy and Governance Division.

Brautigam, D. \& Ekman, S. (2012). Rumours and Realities of Chinese Agricultural Engagement in Mozambique,

African Affairs 111, (444), 483-492.

Brautigam, D. (2015). Will Africa feed China? China, Africa and Global Food Security, Oxford University Press, Oxford.

Buckley, L. (2013). Narratives of China-Africa Cooperation for Agricultural Development: New Paradigm. Working Paper
053 of the China and Brazil in African Agriculture (CBAA) Project work stream. Available at www.future5agricultures.or g.Accessed $16^{\text {th }}$ January, 2017.

Chichava, S., Duran, J., Cabral, L., Shankland, A., Buckley, L., Tang, L \&Yue, Z. (2013). Chinese and Brazilian Cooperation with African Agriculture: The Case of Mozambique. Working Paper 049 of the China and Brazil in African Agriculture (CBAA) Project work stream. Available at www.future5agricultures.or g.Accessed $12^{\text {th }}$ January, 2017.

Coe D. \&Helpman E., (1995). International $\quad R \& D$ Spillovers.European Economic Review, 859-887.

Coe, D, Hess, M. Yeung, H.W-C., Dicken, P. \& Henderson, J. (2004).

'Globalizing' Regional Development: A Global Production Network Perspective", Royal Society of Geography, (29), 468490. 
Cook, S., Lu, J., Tugendhat, H., \&Alemu, D. (2016). 'Chinese Migrants InErnst D. \& Kim L. (2002). Global production networks, knowledge diffusion, and local capability formation. Research Policy, 31, (2), 1417-1429.

Ghana Investment Promotion Authority (GIPA), (2017).

Chinese Investments in

Ghana (1997-2016). Ghana Investment Promotion Authority.

Ghana Investment Promotion Council. (2013). Quarterly Update: Second Quarter 2013 Investment Report $\left(1^{\text {st }}\right.$ April-30 ${ }^{\text {th }}$ June).

Given L. M. (ed) (2008). The Sage Encyclopedia of Qualitative Research Methods.Sage, Thousand Oaks CA. 2, (1), 697-698.

Glaesel, H.\&McCraken, A. (2012). China's Development Initiatives in Ghana, 1961-2011. Journal of Sustainable Development in Africa, 14, (8), 275-286.

Gu, J., Zhang, C., Vaz, A., \& Mukwereza, L. (2016). Chinese State Capitalism?
Rethinking the Role of the State and Business in Chinese Development Cooperation in Africa. World Development, 81, (1), 24-34.

Hallam, D. (2009). Foreign Investment in Developing Country Agriculture-Issues, Policy Implications and International Response, OECD Global Forum on International Investment, Available at http://www.oecd.org/invest ment/globalforum Accessed 5th May, 2016.

Harvey, D. (1975). The Geography of Capitalist Accumulation: A Reconstruction of the Marxian Theory. Antipode, 7, (2), 9-21.

Howaldt, J. \& Schwarz, M. (2010). Social Innovation: Concepts, Research Fields and International Trends. Available online at http://www.internationalmo nitoring.com/fileadmin/Dow nloads/Trendstudien/Trendst udie_Howaldt_englisch.pdf Accessed 5 September 2017. 
Idun-Arkhurst, I. (2008). Ghana's Relations with China, China in Africa Report No. 3, South African Institute of International Affairs, Johannesburg.

Isaksson, A. (2001). Financial Liberalisation, Foreign Aid and Capital Mobility: Evidence from 90 Developing Countries, Journal of International Financial Markets, Institutions and Money, 11, (1), 309-338.

Javorcik, B. S. (2004). Does Foreign Direct Investment Increase the Productivity of Domestic Firms? In Search of Spillovers through

Backward

Linkages.America Economic Review, 94, (3), 605-627.

Kang, B. (2015). What Best Transfers Knowledge? Capital, Goods, and Innovative Labour in East Asia, Institute of Developing Economies Discussion Paper, No. 538.

Kaplinsky, R. (2013). What contribution can China make to inclusive growth in subSaharan Africa?
Development and Change, 44, 1295-1316.

Keller, W. (2002). Trade and transmission of Technology Diffusion as Measured by Patent Citations, Economic Letter, 87, (1), 5-24.

Marfaing, L. \&Theil, A. (2011). Chinese Commodity Imports in Ghana and Senegal: Demystifying Chinese Business Strength in Urban West Africa. GIGA Research Programme.

Marx, K. (1967). Capital: A Critique of Political Economy, Vol. 1, International Publishers New York, NY.

Mason,

(1996). Qualitative Researc hing, Sage, London.

McCann, P. \&Acs, Z. (2009). Globalization: countries, cities and multinationals. Jena Economics Research Papers No. 042.

Ministry of Finance and Economic Planning (2013). Pipeline Projects in Ghana's Public Private Partnership Programme, Accra. Available at http://www.mofep.gov.gh/si 
tes/default.Accessed $\quad 24^{\text {th }}$

December, 2015.

Ministry of Fisheries and

Aquaculture Development (2015).

Fisheries

Management Plan of Ghana:

A National Policy for the

Management of Marine

Fisheries Sector (2015-

2019), Government of

Ghana.

Ministry of Food and Agriculture

(2015). Fisheries. Available at

http://mofa.gov.gh/site/?pag

e $\mathrm{id}=244 . \quad$ Accessed $2^{\text {nd }}$

November, 2017.

Ministry of Trade and Industry. (2017). Imports from China in Ghana, Excel Broad Sheet.

Moyo, S. (2014). Africa Has the Potential to Feed the World, New African, 3, (534), 18.

Mueller, B., \& Mueller, C. (2014).

The economics of the

Brazilian model of agricultural development. IRIBA research programme working paper. Manchester: IRIBA.

Neumeier, S. (2012). Why Do Social Innovations in Rural Development Matter and
Should They be Considered More Seriously in Rural Development Research? Proposal for a Stronger Focus on Social Innovations in Rural Development Research, Rural Sociologica, 52, (1), 49-69.

New African (2014). How Africa can feed Itself? No. 537.

Nyanteng, V. K. \&Dapaah, S. K. (1993). Agricultural Development: Policies and Options. In V.K. Nyanteng (ed) Policies and Options for Ghanaian Economic Development, ISSER.

Oettl, A. \&Agrawal, A. (2008). International Mobility and Knowledge Flow Externalities, Journal of Internal Business Studies, 39, (8), 1242-1260.

Okudzeto, E., Mariki W. A., De Paepe G. \&Sedegah, K. (2014). Ghana 2014: African Economic Outlook. AFDB, OECD, UNDP.

Palys, T. (2012). Purposive Sampling, Simon Fraser University.Available at http://www.sfu.ca/palys/pur posive sampling. 2011. Accessed June 12, 2012. 
Piore, M. \&Sabel, C. (1984). The Second Industrial Divide.Basics Books, New York.

Pot, F. \&Vaas, F. (2008). Social Innovation. The New Challenge for Europe. International Journal of Productivity and

Performance Management, 57, (6), 468-473.

Rodrigue, J-P \&Notteboom, T. (2017).The Geography of Transport Systems. Fourth Edition, Routledge, New York.

Rodrik, D. (2011). The Globalization Paradox: Why Global Markets, States, and Democracy Can't Coexist, Oxford University Press, Oxford.

Schoneveld, G., \& German, L. (2014). Translating Legal Rights into Tenure Security: Lessons from the New Commercial Pressures on Land in Ghana.Journal of Development Studies, 50, (2), 187-203.

Schumpeter, J. A. (2004). The Theory of Economic Development, Transaction
Publishers, New Brunswick, NJ.

Scoones, I., Amanor, K., Favareto, A. \& Qi, G. (2016). A New Politics of Development Cooperation? Chinese and Brazilian Engagements in African Agriculture.World Development, 81, 1-12.

Seini, A.W. (2002). Agricultural Growth and Competiveness under Policy Reforms in Ghana, Technical Publication, No.61, ISSER, University of Ghana, Legon. Snyder, F. (1999). Governing Economic Globalization: Global Legal Pluralism and European Union Law, European Law Journal, Special Issue on 'Law and Globalisation', 5, (4), 334374.

Tang, X. (2017). Chinese Investment in Ghana's Manufacturing Sector. IFPRI Discussion Paper 01628, Development Strategy and Governance Division.

Tesch, R. (1990). Qualitative Research. Falmer, New York. 
Thorne, S. (2000). Data Analysis in Qualitative Research, 3, (1), 68-70. Available at http://ebn.bmj.com/content/. Accessed 14 $4^{\text {th }}$ July, 2015.

Todaro, M. \& Smith S. C. (2009). Economic Development $\left(10^{\text {th }}\right.$ Edition), Pearson Education Limited, England.

Tsikata, D., Fenny, A. P. \&Aryeetey, E. (2008). China-Africa Relations: A Case Study of Ghana. A Draft Scoping Study.AERC. Available at www.africaportal.org.

Vaz, A. C. (2015). International Drivers of Brazilian Agricultural Cooperation in Africa in the Post-2008 Economic Crisis, Review of Brazilian Polity International, 58, (1), 164190.

Walker, R. A. (1978). Two Sources of Uneven Development under Advanced Capitalism: Spatial Differentiation and Capital Mobility, Review of Radical Political

Economics, 10, (3), 28-37. Wallace, M. \& Sheldon, N. (2015). Business Research
Ethics: Participant Observer Perspectives, Journal of Business Ethics, 128, (2), 267-277.

World Trade Organization (2014).Annual Report 2014. Available at https://www.wto.org/english /res e/booksp e/anrep e/anr ep14_e.pdf.Accessed July 2 2018.

Xu, X., Li, X., Qi, G., Tang, L., \& Mukwereza, L. (2016). Science, Technology, and the Politics of Knowledge: The Case of China's Agricultural Technology Demonstration Centres in Africa. World Development, 81, (82-91). 